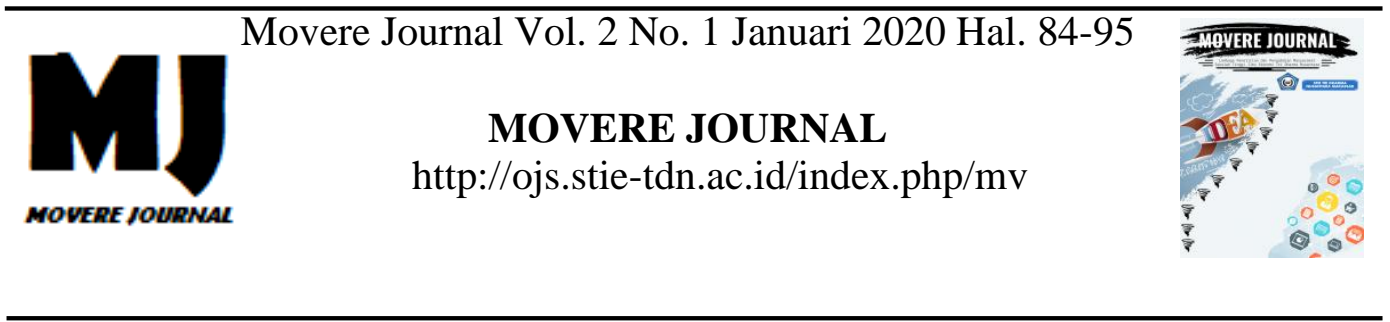

\title{
PENGARUH KEPEMIMPINAN, MOTIVASI KERJA DAN DISIPLIN KERJA TERHADAP KINERJA PEGAWAI PADA KANTOR PEMERINTAH KOTA MAKASSAR
}

\section{Roswiyanti}

\begin{abstract}
Abstrak : Tujuan dari penelitian ini adalah untuk mengetahui pengaruh kepemimpinan, motivasi kerja, dan disiplin kerja terhadap kinerja pegawai Kantor Pemerintah Kota Makassar. Dan pengaruh kepemimpinan, motivasi, dan disiplin kerja secara bersama-sama terhadap kinerja pegawai Kantor Pemerintah Kota Makassar. Adapun yang menjadi sampel dalam penelitian ini adalah semua pegawai Kantor Pemerintah Kota Makassar yang berjumlah 154 orang. Sedangkan teknik analisis data yang digunakan yaitu analisis linear regesi berganda dan uji t serta uji F. Berdasarkan hasil penelitian terlihat bahwa variabel kepemimpinan berpengaruh signifikan terhadap kinerja dan variabel kepemimpinan, motivasi, dan disiplin kerja berpengaruh secara bersama-sama terhadap kinerja pegawai Kantor Pemerintah Kota Makassar. Nilai koefisien determinasi yang disesuaikan (adjusted $\mathrm{R}^{2}$ ) adalah 0,441 artinya $44,1 \%$ variasi dari semua variabel bebas (kepemimpinan, motivasi kerja dan disiplin kerja) dapat menerangkan variabel tak bebas (Kinerja Pegawai).
\end{abstract}

Keyword : Kepemimpinan, Motivasi Kerja, Disiplin Kerja dan Kinerja

\section{PENDAHULUAN}

Sumber daya manusia merupakan tokoh sentral dalam organisasi agar aktivitas manajemen berjalan dengan baik, Kantor Pemerintah Kota Makassar harus memiliki pegawai yang berpengetahuan dan berketerampilan tinggi serta usaha untuk mengelola Kantor Pemerintah Kota Makassar seoptimal mungkin sehingga kinerja pegawai meningkat. Kinerja yang baik adalah kinerja yang optimal, yaitu kinerja yang sesuai standar organisasi dan mendukung tercapainya tujuan organisasi. Hal ini sesuai dengan pengertian kinerja menurut Guritno dan Waridin (2005:84) kinerja merupakan perbandingan hasil kerja yang dicapai oleh pegawai dengan standar yang telah ditentukan dengan SDM kepemimpinan yang baik terhadap bawahannya.

Peningkatan kinerja pegawai akan membawa kemajuan bagi Kantor Pemerintah Kota Makassar untuk dapat bertahan dalam suatu persaingan lingkungan bisnis yang tidak stabil. Kinerja merupakan perbandingan hasil kerja yang dicapai oleh pegawai dengan standar yang telah ditentukan 
(Guritno dan Waridin, 2005). Oleh karena itu upaya-upaya untuk meningkatkan kinerja pegawai merupakan tantangan manajemen yang paling serius karena keberhasilan untuk mencapai tujuan dan kelangsungan hidup Kantor Pemerintah Kota Makassar tergantung pada kualitas kinerja sumber daya manusia yang ada didalamnya.

Faktor-faktor yang dapat digunakan untuk meningkatkan kinerja diantaranya adalah kepemimpinan, motivasi dan disiplin kerja. Kepemimpinan menurut Hasibuan (2007:170), kepemimpinan adalah cara seseorang memimpin mempengaruhi prilaku bawahannya agar mau bekerja sama dan bekerja secara produktif untuk mencapai tujuan organisasi. Pemimpin yang baik akan mampu memotivasi pegawainya dalam bekerja. Hal ini dapat berupa motivasi yang diberikan pimpinan terhadap penyelesaian kerja pegawai, penghargaan yang diberikan pimpinan maupun organisasi terhadap hasil kerja pegawai.

Fenomena kepemimpinan di lapangan adalah masih dijumpai kebijakan pimpinan yang tidak melibatkan bawahan terkait dalam menetapkan target organisasi. Selain itu fenomena yang tergambar adalah masih terlihat hubungan yang kaku antara bawahan dan atasan yang kurang komunikatif sehingga keluhan dan masalah pegawai dilapangan tidak tersampaikan secara sempurna kepada atasan. Dampaknya adalah permasalan tersebut terpendam di bawah dan atasan terkesan menekan bawahan dengan target-target dan tugas-tugas sehingga pegawai tidak nyaman dalam bekerja dan mencapai target. Fenomena lain adalah Kurang tegasnya pimpinan dalam menegakkan peraturan dan aturan yang telah di tetapkan, seperti : kurangnya pemberian sangsi kepada pegawai yang tidak menegakkan aturan atau melanggar aturan kerja.

Salah satu syarat agar disiplin dapat ditumbuhkan dalam lingkungan kerja ialah, adanya pembagian kerja yang tuntas sampai kepada pegawai atau petugas yang paling bawah, sehingga setiap orang tahu dengan sadar apa tugasnya, bagaimana melakukannya, kapan pekerjaan dimulai dan selesai, seperti apa hasil kerja yang diinginkan, dan kepada siapa mempertanggung jawabkan hasil pekerjaan itu. Tanpa adanya disiplin yang baik, jangan harap akan dapat diwujudkan adanya sosok pemimpin sebagaimana yang diharapkan oleh organisasi dan masyarakat. Kinerja pegawai sangat diperlukan untuk mencapai tujuan organisasi. Hal tersebut sangat berkaitan dengan beberapa faktor yang mempengaruhinya, seperti kepemimpinan, motivasi, dan disiplin kerja pegawai karena tanpa kepemimpinan yang baik, motivasi yang ada serta disiplin kerja yang bagus dari pegawai akan sulit dicapai kinerja pegawai yang diharapkan dalam organisasi.

Berdasarkan uraian diatas, maka peneliti tertarik untuk melakukan penelitian yang berjudul "Pengaruh Kepemimpinan, Motivasi Kerja dan Disiplin Kerja terhadap Kinerja Pegawai Kantor Pemerintah Kota Makassar".

Berdasarkan permasalahan yang telah diuraikan di atas, maka dirumuskan masalah penelitian sebagai berikut :
1. Bagaimana
kepemimpinan berpengaruh 
pegawai Kantor Pemerintah Kota Makassar?

2. Bagaimana motivasi kerja berpengaruh terhadap kinerja pegawai Kantor Pemerintah Kota Makassar?

3. Bagaimana disiplin kerja berpengaruh terhadap kinerja pegawai Kantor Pemerintah Kota Makassar?

4. Bagaimana kepemimpinan, motivasi, dan disiplin kerja berpengaruh secara bersama-sama terhadap kinerja pegawai Kantor Pemerintah Kota Makassar ?

Berdasarkan latar belakang dan rumusan masalah yang ada, maka penelitian ini dilakukan dengan tujuan:

1. Untuk mengetahui pengaruh variabel kepemimpinan terhadap kinerja pegawai Kantor Pemerintah Kota Makassar.

2. Untuk mengetahui pengaruh variabel motivasi terhadap kinerja pegawai Kantor Pemerintah Kota Makassar.

3. Untuk mengetahui pengaruh variabel disiplin kerja terhadap kinerja pegawai Kantor Pemerintah Kota Makassar.

4. Untuk mengetahui pengaruh kepemimpinan, motivasi, dan disiplin kerja terhadap kinerja pegawai Kantor Pemerintah Kota Makassar.

\section{TELAAH LITERATUR DAN PENGEMBANGAN HIPOTESIS}

\section{Pengertian Kepemimpinan}

Menurut Hasibuan (2001:167) kepemimpinan adalah cara seorang pemimpin mempengaruhi perilaku bawahannya, agar mau bekerjasama dan bekerja secara produktif untuk mencapai tujuan organisasi. Kepemimpinan adalah suatu seni atau kemampuan dalam mempengaruhi dan menggerakkan staf yang dalam hal ini pegawai agar bisa menjalankan tugas dengan penuh tanggung jawab. Pemimpinlah yang bertanggung jawab didalam menciptakan lingkungan kerja yang kondusif dan aman sehingga orangorang dapat bekerja dengan penuh semangat.

Menurut Hasibuan (2005:170), bahwa kepemimpinan adalah seni seorang pemimpin mempengaruhi bawahannya, agar mau bekerjasama dan bekerja secara produktif untuk mencapai tujuan organisasi. Menurut Terry (2003:5) : " Leadership is activity of influence people to strive wilingly for matual objectives ", Kepemimpinan adalah keseluruhan kegiatan untuk mempengaruhi orang lain untuk mencapai tujuan bersama.

Menurut Ridwan (2004:65) menyatakan bahwa indikator yang dapat mempengaruhi kepemimpinan adalah sebagai berikut :

1. Pematangan penyiapan pengikut, hal itu dapat ditunjukkan melalui pemberian penerangan yang jelas, keterangan yang factual, pengertian yang jelas, pendidikan, pengetahuan/pikiran serta adat istiadat.

2. Hubungan antar manusia, ditunjukkan melalui memahami dan mendalami bawahan, menyamakan persepsi, pencapaian tujuan organisasi serta kepentingan organisasi.

3. Menjadi teladan, ditunjukkan melalui hakekat pemberian teladan, pengaruh pada bawahan, wujud perbuatan, larangan, anjuran serta keharusan.

4. Persuasi dan pemberi perintah, ditunjukkan melalui ajakan simpatik dari pimpinan, kemauan tanpa paksaan, kesadaran, 
pemberian perintah, pelaksanaan perintah serta ketaatan.

5. Penggunaan komunikasi yang tepat, ditunjukkan melalui kejelasan informasi, penerangan, kegiatan organisasi serta

7. iatan organisasi serta alat pencapaian tujuan organisasi.

\section{Pengertian Motivasi Kerja}

Motivasi berasal dari bahasa latin movere yang berarti dorongan atau penggerakan. Secara umum motivasi dapat diartikan sebagai dorongan dan keinginan serta upaya yang muncul dari diri seorang individu untuk melakukan suatu hal. Robbin (2002:55) dalam Brahmasari dan Suprayetno (2008:125) mengemukakan bahwa motivasi adalah keinginan untuk melakukan sebagai kesediaan untuk mengeluarkan tingkat upaya yang tinggi untuk tujuan organisasi, yang dikondisikan oleh kemampuan upaya itu untuk memenuhi suatu kebutuhan individual. Menurut Ridwan (2002:66) bahwa motivasi kerja dapat diukur melalui indikator sebagai berikut :

1. Upah / Gaji yang layak, yang dapat diukur melalui gaji yang memadai dan besarnya sesuai standar mutu hidup

2. Pemberian insentif, yang diukur melalui pemberian bonus sewaktu-waktu, rangsangan kerja, prestasi kerja

3. Memenuhi kebutuhan partisipasi, yaitu diukur melalui kebersamaan, kerjasama, rasa memiliki, dan bertanggung jawab.

4. Menempatkan pegawai pada tempat yang sesuai, dalam hal ini diukur dengan seleksi sesuai kebutuhan, memperhatikan kemampuan, memperhatikan pendidikan, memperhatikan kesamaan persepsi.

6. Penyediaan fasilitas, ditunjukkan melalui jenis fasilitas yang disediakan, pencapaian tujuan, petunjuk teknik, keg

pengalaman, memberikan pekerjaan sesuai kemampuan.

5. Menimbulkan rasa aman di masa depan, seperti indikator penyelenggaraan jaminan hari tua, pembayaran pensiun, pemberian perumahan.

6. Memperhatikan lingkungan tempat kerja, yang diukur melalui tempat kerja yang nyaman, cukup cahaya, jauh dari polusi dan berbahaya.

7. Memperhatikan kesempatan untuk maju, yang diukur dengan memberikan upaya pengembangan, kursus, diklat.

\section{Pengertian Disiplin Kerja}

Secara etimologis, kata "disiplin" berasal dari bahasa latin "diciplina" yang berarti latihan atau pendidikan kesopanan dan kerohanian serta pengembangan tabiat. Secara umum disiplin kerja dapat diartikan sebagai ketaatan atau kepatuhan kepada peraturan yang ada atau disiplin kerja adalah suatu sikap yang mencerminkan ketaatan terhadap suatu peraturan dan norma serta tata cara yang berlaku. Menurut saydam (2000 : 23) menyatakan disiplin merupakan kemampuan untuk menguasai diri sendiri dan melaksanakan norma-norma yang berlaku dalam kehidupan, mentaati tata cara yang telah ditentukan dalam kehidupan, mentaati tata cara yang telah ditentukan dalam melaksanakan tugas dan tanggung jawab yang telah diserahkan kepada setiap orang sehingga dapat dijalankan dengan penuh kesadaran. 
Menurut Soejono (2000:67) ada beberapa indikator disiplin kerja pegawai yaitu sebagai berikut :

1. Ketepatan waktu

Para pegawai datang ke kantor tepat waktu, tertib dan teratur, dengan begitu dapat dikatakan disiplin kerja baik.

2. Menggunakan peralatan kantor dengan baik

Sikap hati-hati dalam menggunakan peralatan kantor dapat mewujudkan bahwa seseorang memiliki disiplin kerja yang baik, sehingga peralatan kantor dapat terhindar dari kerusakan.

3. Tanggung jawab yang tinggi

Pegawai yang senantiasa menyelesaikan tugas yang dibebankan kepadanya sesuai dengan prosedur dan bertanggung jawab atas hasil kerja, dapat pula dikatakan memiliki disiplin kerja yang baik.

4. Ketaatan terhadap aturan kantor Pegawai memakai seragam kantor, menggunakan kartu tanda pengenal/identitas, membuat ijin bila tidak masuk kantor, juga merupakan cerminan dari disiplin yang tinggi.

\section{Pengetian Kinerja}

Menurut Rivai dan Basri (2005) kinerja adalah kesediaan seseorang atau kelompok orang untuk melakukan sesuatu kegiatan dan menyempur-nakannya sesuai dengan tanggung jawab dengan hasil seperti yang diharapkan. Menurut Hasibuan (2005), kinerja (prestasi kerja) adalah suatu hasil kerja yang dicapai seseorang dalam melaksanakan tugas-tugas yang dibebankan kepadanya yang didasarkan atas kecakapan, pengalaman dan kesungguhan serta waktu.

Menurut Hasibuan (2005:94) bahwa indikator yang digunakan untuk menilai kinerja karyawan antara lain adalah sebagai berikut :

1. Prestasi Kerja.

Hasil prestasi kerja karyawan, baik kualitas maupun kuantitas dapat menjadi tolak ukur kinerja.

2. Kedisiplinan

Kedisiplinan karyawan dalam mematuhi peratura yang ada dan melaksanakan instruksi yang diberikan kepadanya dapat menjadi tolak ukur kinerja.

3. Kerjasama

Diukur dari kesediaan karyawan dalam berpartisipasi dan bekerja sama dengan karyawan lain sehingga hasil pekerjaanya akan semakin baik.

4. Keterampilan

Keterampilan karyawan dalam menyelesaikan pekerjaan yang telah dibebankan kepadanya juga menjadi tolak ukur dalam meningkatkan kinerja.

5. Tanggung Jawab

Kinerja karyawan juga dapat diukur dari kesediaan karyawan dalam mempertanggungjawabkan pekerjaan dan hasil kerjanya.

\section{Kerangka Pikir}

Pengaruh kepemimpinan, motivasi dan disiplin kerja terhadap kinerja pegawai, secara skematis digambarkan seperti pada gambar dibawah ini: 


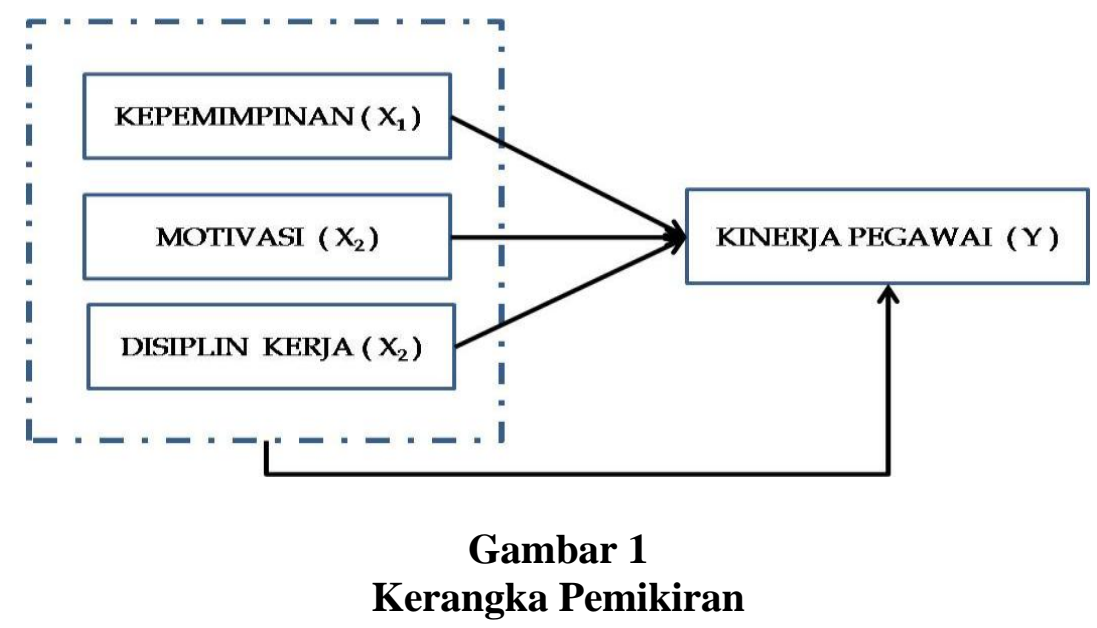

\section{Hipotesis}

Berdasarkan perumusan masalah dan dikaitkan dengan landasan teori yang digunakan, maka peneliti dapat mengemukakan hipotesis sebagai berikut :

H1 : Diduga kepemimpinan berpengaruh signifikan terhadap kinerja pegawai Kantor Pemerintah Kota Makassar.

$\mathrm{H} 2$ : Diduga motivasi berpengaruh signifikan terhadap kinerja pegawai Kantor Pemerintah Kota Makassar.

H3 : Diduga disiplin kerja berpengaruh signifikan terhadap kinerja pegawai Kantor Pemerintah Kota Makassar.

H4 : Diduga kepemimpinan, motivasi, dan disiplin kerja secara bersama berpengaruh signifikan terhadap kinerja pegawai Kantor Pemerintah Kota Makassar.

\section{METODE PENELITIAN}

\section{Jenis Metodologi Penelitian}

Adapun metode penelitian yang digunakan adalah Metodologi Kuantitatif, diartikan sebagai metode penelitian yang digunakan untuk meneliti populasi atau sampel pada umumnya dilakukan secara random, pengumpulan data menggunakan instrumen penelitian, analisis data bersifat kuantitatif atau statistik dengan tujuan untuk menguji hipotesis yang telah ditetapkan (Sugiyono, 2007 : 13).

\section{Populasi dan Sampel Penelitian}

1. Populasi

Populasi adalah totalitas semua nilai yang mungkin, baik hasil menghitung ataupun pengukuran kuantitatif maupun kualitatif pada karakteristik tertentu mengenai objek yang lengkap (Ridwan, 2008:54). Populasi adalah wilayah generalisasi yang terdiri dari objek atau subjek yang menjadi kuantitas dan karakteristik tertentu yang diterapkan oleh peneliti untuk dipelajari dan kemudian ditarik kesimpulan (Sugiyono, 2009). Populasi dalam penelitian ini adalah semua Pegawai Kantor Pemerintah Kota Makassar yang berjumlah 154 orang.

2. Sampel

Sampel adalah sebagai bagian dari populasi, yang terdiri dari beberapa anggota yang dipilih dari elemen populasi (Sugiyono, 2009). Pengambilan sampel dilakukan (C) 2020 STIE TDN. All rights reserved 
dengan metode Proportional Random Sampling adalah proses pengambilan sampel dilakukan dengan memberi kesempatan yang sama pada setiap anggota populasi untuk menjadi anggota sampel. Jumlah sampel dengan menggunakan rumus Slovin (Umar, 2007:78) :

$n=\frac{N}{1+N(e)^{2}}$

Dimana :

$$
\begin{array}{rlr}
\mathrm{n}= & \text { Ukuran Sampel } \\
\mathrm{N}= & \text { Ukuran Populasi } \\
\mathrm{e}= & \text { persen } & \text { kelonggaran } \\
& \text { ketidaktelitian } & \text { karena } \\
& \text { kesalahan } & \text { pengambilan } \\
& \text { sampel yang } & \text { masih ditolerir } \\
& (5 \%-10 \%) .
\end{array}
$$

Sehingga sampel yang digunakan :

$$
\begin{aligned}
n & =\frac{154}{1+154(10 \%)^{2}} \\
& =60,63 \\
n & =61
\end{aligned}
$$

\begin{tabular}{|c|c|c|c|c|c|c|c|c|}
\hline \multicolumn{9}{|c|}{ Coefficients ${ }^{\mathrm{a}}$} \\
\hline & & \multicolumn{2}{|c|}{$\begin{array}{l}\text { Unstandardized } \\
\text { Coeff icients }\end{array}$} & $\begin{array}{l}\text { Standardized } \\
\text { Coeff icients }\end{array}$ & \multirow[b]{2}{*}{$\mathrm{t}$} & \multirow[b]{2}{*}{ Sig. } & \multicolumn{2}{|c|}{ Collinearity Statistics } \\
\hline \multicolumn{2}{|c|}{ Model } & B & Std. Error & Beta & & & Tolerance & VIF \\
\hline \multirow[t]{4}{*}{1} & (Constant) & 8.952 & 4.441 & & 2.016 & .049 & & \\
\hline & Kepemimpinan (X1) & .210 & .101 & .247 & 2.085 & .042 & .665 & 1.504 \\
\hline & Motivasi Kerja (X2) & .210 & .097 & .293 & 2.158 & .035 & .505 & 1.980 \\
\hline & Disiplin Kerja (X3) & .274 & .128 & .274 & 2.146 & .036 & .574 & 1.743 \\
\hline
\end{tabular}

Maka jumlah sampel yang akan diambil dalam penelitian ini adalah 61 orang yang akan dijadikan responden.

\section{Teknik Pengumpulan Data}

Tabel 1: Hasil Regresi Untuk Kepemimpinan, Motivasi Kerja,Disiplin Kerja TerhadapKinerja

Sumber : Data diolah, 2012

Berdasarkan tabel maka bentuk model persamaan regresi untuk pengaruh kemimpinan, motivasi kerja dan disiplin kerja terhadap kinerja pegawai Kantor Pemerintah Kota Makassar, adalah sebagai
Menurut Arikunto (2002 : 207) teknik pengumpulan data dalam penelitian dilakukan dengan dua cara yaitu : Angket dan Kepustakaan.

\section{Analisis Data}

Metode analisis data yang dipergunakan dalam penelitian ini adalah dengan menggunakan beberapa teknik analisa statistik melalui pemanfaatan Statistical Package for Social Science (SPSS) versi 19.0 for Windows antara lain adalah : Analisa Regresi Linear Berganda, Pengujian Hipotesis dan Koefisien Determinasi.

\section{HASIL PENELITIAN DAN PEMBAHASAN}

\section{Analisis Regresi Linear \\ Hasil pengujian analisis berganda untuk mengukur pengaruh kepemimpinan, motivasi kerja dan disiplin kerja terhadap kinerja pegawai pada Kantor Pemerintah Kota Makassar dengan bentuk output SPSS seperti yang dikemukakan pada tabel berikut ini :}


1. Nilai konstanta adalah 8,952 artinya tanpa adanya pengaruh kepemimpinan, motivasi kerja dan disiplin kerja, maka kinerja pegawai pada Kantor Pemerintah Kota Makassar, sudah ada sebesar $8,95 \%$.

2. Nilai koefisien regresi kepemimpinan adalah 0,210 artinya setiap peningkatan satu satuan kepemipinan maka kinerja pegawai pada Kantor Pemerintah Kota Makassar sebesar 21\%.

3. Nilai koefisien regresi motivasi kerja adalah 0,210 artinya setiap peningkatan satu satuan motivasi kerja maka kinerja pegawai pada Kantor Pemerintah Kota Makassar meningkat sebesar $21 \%$.
4. Nilai koefisien regresi disiplin kerja adalah 0,274 artinya setiap peningkatan satu satuan disiplin kerja maka kinerja pegawai pada Kantor Pemerintah Kota Makassar meningkat sebesar $27,4 \%$.

\section{Uji t}

Untuk mengetahui ada atau tidak adanya pengaruh signifikan kepemimpinan, motivasi kerja dan disiplin kerja secara satu persatu terhadap kinerja pegawai pada Kantor Pemerintah Kota Makassar, maka dilakukanlah uji t. Berdasarkan hasil yang ditemukan dari pengujian t-statistik lewat bantuan program SPSS ditemukan hasil seperti terlihat pada tabel.

Tabel 2: Hasil Uji t untuk Kepemimpinan, Motivasi Kerja dan Disiplin Kerja Terhadap Kinerja Pegawai

\begin{tabular}{|c|c|c|c|c|c|}
\hline \multirow[t]{2}{*}{ Model } & \multicolumn{2}{|c|}{$\begin{array}{l}\text { Unstandardized } \\
\text { Coefficients }\end{array}$} & \multirow{2}{*}{$\begin{array}{c}\text { Standardized } \\
\text { Coefficients } \\
\text { Beta } \\
\end{array}$} & \multirow[t]{2}{*}{$\mathrm{t}$} & \multirow[t]{2}{*}{ Sig. } \\
\hline & $\mathrm{B}$ & Std. Error & & & \\
\hline 1 (Constant) & 8,952 & 4.441 & & 2.016 & .049 \\
\hline Kepemimpinan (X1) & .210 & .101 & .247 & 2.085 & .042 \\
\hline Motivasi Kerja (X2) & .210 & .097 & .293 & 2.158 & .035 \\
\hline Disiplin Kerja (X3) & .274 & .128 & .274 & 2.146 & .036 \\
\hline
\end{tabular}

Sumber : Data diolah, 2012

Berdasarkan ringkasan uji $t$ seperti yang dikemukakan pada tabel diatas diketahui :

1. Hasil uji t untuk pengaruh kepemimpinan terhadap kinerja pegawai pada Kantor Pemerintah Kota Makassar menghasilkan nilai t-hitung 2,085 lebih besar dari nilai $t$ tabel 2,002 dengan nilai signifikannya 0,042 atau lebih kecil dari level of significant $(\alpha)$ 0,05. Dari hasil uji $\mathrm{t}$ ini dapat disimpulkan bahwa kepemimpinan berpengaruh signifikan terhadap kinerja pegawai pada Kantor Pemerintah Kota Makassar, sehingga bentuk pengujian hipotesisnya adalah $\mathrm{Ha}$ diterima.

2. Hasil uji t untuk pengaruh motivasi kerja terhadap kinerja pegawai pada Kantor Pemerintah Kota Makassar menghasilkan nilai t-hitung 2,158 lebih besar dari nilai $\mathrm{t}$ tabel 2,002 dengan nilai signifikannya 0,035 atau lebih kecil dari level of significant $(\alpha)$ 0,05. Dari hasil uji t ini dapat disimpulkan bahwa motivasi kerja berpengaruh signifikan terhadap kinerja pegawai pada Kantor Pemerintah Kota Makassar, sehingga bentuk pengujian hipotesisnya adalah Ha diterima. 
3. Hasil uji t untuk pengaruh disiplin kerja terhadap kinerja pegawai pada Kantor Pemerintah Kota Makassar menghasilkan nilai thitung 2,146 lebih besar dari nilai $\mathrm{t}$ tabel 2,002 dengan nilai signifikannya 0,036 atau lebih kecil dari level of significant $(\alpha)$ 0,05. Dari hasil uji $\mathrm{t}$ ini dapat disimpulkan bahwa disiplin kerja berpengaruh signifikan terhadap kinerja pegawai pada Kantor Pemerintah Kota Makassar, sehingga bentuk pengujian hipotesisnya adalah Ha diterima.

Dari hasil uji t tersebut, maka dapat diketahui yang paling berpengaruh signifikan terhadap kinerja pegawai pada Kantor Pemerintah Kota Makassar adalah motivasi kerja pegawai karena nilai $t$ (hitung) motivasi kerja adalah 2,158 lebih besar dari nilai $t$ (hitung) disiplin kerja 2,146 dan (t hitung) kepemimpinan 2,085. Sehingga dari ketiga variabel bebas ini yaitu kepemimpinan, motivasi kerja dan disiplin kerja pegawai, maka langkah yang perlu diambil terlebih dahulu oleh pada Kantor Pemerintah Kota Makassar memberikan motivasi kerja yang lebih baik lagi. Setelah melakukan motivasi kerja yang baik, maka baru dilanjutkan dengan menciptakan disiplin kerja yang sesuai dengan aturan serta pimpinan yang mampu mengerti keadaan bawahan dan mampu bekerja sama dengan bawahannya.

\section{Uji F}

Untuk mengetahui ada atau tidak adanya pengaruh signifikan kepemimpinan, motivasi kerja dan disiplin kerja secara bersama-sama terhadap kinerja pegawai pada Kantor Pemerintah Kota Makassar maka dilakukanlah uji $F$. Berdasarkan hasil yang ditemukan dari pengujian F-statistik lewat bantuan program SPSS ditemukan hasil seperti terlihat pada tabel dibawah ini :

\section{Tabel 3 : Hasil Uji F untuk Kepemimpinan, Motivasi Kerja dan Disiplin KerjaTerhadap Kinerja Pegawai}

ANOVA

\begin{tabular}{|c|c|c|c|c|c|c|}
\hline \multicolumn{2}{|c|}{ Model } & $\begin{array}{l}\text { Sum of } \\
\text { Squares }\end{array}$ & $\mathrm{df}$ & Mean Square & $\mathrm{F}$ & Sig. \\
\hline \multirow[t]{3}{*}{1} & Regression & 643.861 & 3 & 214.620 & 16.760 & $.000^{\mathrm{a}}$ \\
\hline & Residual & 729.909 & 57 & 12.805 & & \\
\hline & Total & 1373.770 & 60 & & & \\
\hline
\end{tabular}

a.

Predictors: (Constant), Disiplin Kerja (X3), Kepemimpinan (X1), Motivasi Kerja (X2)

b. Dependent Variable: Kinerja (Y)

Sumber : Data diolah, 2012

Berdasarkan ringkasan uji $\mathrm{F}$ seperti yang dikemukakan pada tabel diatas diketahui bahwa $\boldsymbol{F}$ hitung adalah 16,760 lebih besar dari pada nilai $F$ tabel adalah 2,77 dengan nilai sigfikannya 0,000 atau lebih kecil dari level of significant ( $\alpha$ ) 0,05. Dari hasil uji $F$ ini dapat disimpulkan bahwa kepemimpinan, motivasi kerja dan disiplin kerja secara bersama-sama berpengaruh signifikan terhadap kinerja pegawai 
Kantor Pemerintah Kota Makassar sehingga pengujian hipotesisnya adalah Ha diterima.

Hasil uji $\mathrm{F}$ ini juga menunjukkan bahwa kepemimpinan, motivasi kerja dan disiplin kerja mempunyai pengaruh yang menentukan untuk meningkatkan kinerja pegawai pada Kantor Pemerintah Kota Makassar. Untuk itu, usaha-usaha untuk perbaikan terhadap pemimpin yang dapat memberi contoh yang baik kepada bawahannya dan dapat bekerja sama terhadap bawahannya dan usaha-usaha untuk memotivasi diri agar bekerja lebih giat lagi serta berusaha untuk meningkatkan disiplin kerja agar tercapai tujuan dan sasaran oraganisasi.

\section{Koefisien Determinasi}

Analisis koefisien determinasi untuk kepemimpinan, motivasi kerja dan disiplin kerja terhadap kinerja pegawai pada Kantor Pemerintah Kota Makassar dilakukan dengan menggunakan program SPSS dengan bentuk output SPSS seperti yang dikemukakan dibawah ini :

Tabel 4

Hasil Koefisien Determinasi

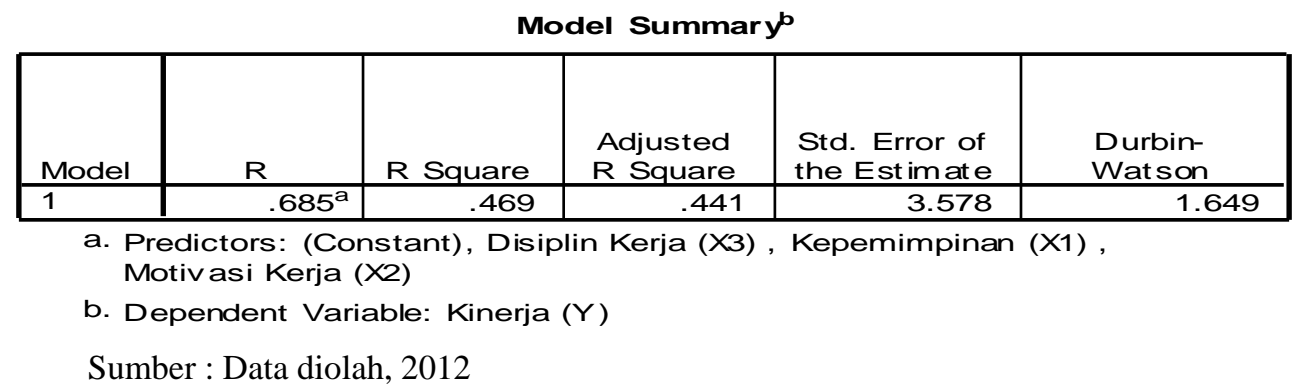

Dari tabel diatas dietahui bahwa nilai koefisien determinasi adalah 0,441 berarti besarnya pengaruh kepemimpinan, motivasi kerja dan disiplin kerja secara bersamaan terhadap kinerja pegawai pada Kantor Pemerintah Kota Makassar adalah sebesar $44,1 \%$ dan sisanya sebesar $55,9 \%$ dipengaruhi oleh selain variabel kepemimpinan, motivasi kerja dan disiplin kerja, misalnya kompensasi, kompetensi, semangat kerja, iklim kerja, dan lain sebagainya. Dari hasil koefisien determinasi tersebut maka dapat disimpulkan bahwa pegawai pada Kantor Pemerintah Kota Makassar akan mengalami peningkatan kinerja jika kepemimpinan, motivasi kerja dan disiplin kerja dapat mendukung

pelaksanaan tugas atau program kerja yang dilakukan oleh pegawai.

\section{KESIMPULAN}

Berdasarkan hasil penelitian dan analisa data yang dilakukan mengenai pengaruh kepemimpinan, motivasi kerja dan disiplin kerja terhadap kinerja pegawai pada Kantor Pemerintah Kota Makassar maka dapat dikemukakan kesimpulan penelitian sebagai berikut :

1. Kepemimpinan berpengaruh signifikan terhadap kinerja pegawai pada Kantor Pemerintah Kota Makassar sebesar 0,210 atau $21 \%$, dimana nilai t-hitung 2,085 lebih besar dari nilai t tabel 2,002 
dengan nilai signifikannya 0,042 atau lebih kecil dari level of significant $(\alpha) 0,05$.

2. Motivasi kerja berpengaruh signifikan terhadap kinerja pegawai pada Kantor Pemerintah Kota Makassar sebesar 0,210 (21\%) dimana nilai t-hitung 2,158 lebih besar dari nilai t tabel 2,002 dengan nilai signifikannya 0,035 atau lebih kecil dari level of significant $(\alpha) 0,05$.

3. Disiplin kerja berpengaruh signifikan terhadap kinerja pegawai pada Kantor Pemerintah Kota Makassar sebesar 0,274 $(27,4 \%)$, dimana nilai t-hitung 2,146 lebih besar dari nilai t tabel 2,002 dengan nilai signifikannya 0,036 atau lebih kecil dari level of significant $(\alpha) 0,05$.

4. Kepemimpinan, Motivasi Kerja dan Disiplin Kerja secara bersamaan berpengaruh signifikan terhadap kinerja pegawai pada Kantor Pemerintah Kota Makassar sebesar 0,441 $(44,1 \%)$ sisanya sebesar $55,9 \%$ dipengaruhi oleh variabel lain yang tidak diteliti dalam penelitian ini. Dimana nilai $\mathrm{F}$ hitung adalah 16,760 lebih besar dari pada nilai $\mathrm{F}$ tabel adalah 2,77 dengan nilai sigfikannya 0,000 atau lebih kecil dari level of significant $(\alpha) 0,05$.

\section{DAFTAR PUSTAKA}

Dessler, Gary. 2009. Manajemen SDM buku 1. Jakarta : Indeks

Galih, Rahmat. 2013. Pengaruh Motivasi Dan Disiplin Kerja Terhadap Kinerja Pegawai Pada Dinas Komunikasi Dan Informatika Provinsi Jawa Barat.

Gibson. 2003. Organisasi : Perilaku, struktur dan proses. Erlangga, Jakarta.

Guritno, Bambang dan Waridin. 2005. Pengaruh Persepsi Pegawai Mengenai Perilaku Kepemimpinan, Kepuasan Kerja Dan Motivasi Terhadap Kinerja. JRBI. Vol 1. No 1. Hal: 63-74.

Hakim, Abdul. 2006. Analisis Pengaruh Motivasi, Komitmen Organisasi Dan Iklim Organisasi Terhadap Kinerja Pegawai Pada Dinas Perhubungan

DanTelekomunikasi Provinsi Jawa Tengah. JRBI. Vol 2. No 2. Hal: 165-180.

Handoko, T. Hani. 2003. Manajemen Edisi 2 . BPFE. Yogyakarta.

Hasibuan, Malayu S. P. 2008. Manajemen Sumber Daya Manusia. Jakarta: PT. Bumi Aksara.

Kuncuro, M. 2003. Metode Riset untuk Bisnis \& Ekonomi, Bagaimana Meneliti \& Menulis Tesis. Erlangga, Jakarta.

Masrukhin dan Waridin. 2004. Pengaruh Motivasi Kerja, Kepuasan Kerja, Budaya Organisasi Dan Kepemimpinan Terhadap Kinerja Pegawai. EKOBIS .Vol 7. No 2. Hal: 197-209.

Ridwan. 2008. Metode dan Teknik Menyusun Tesis. Bandung: Alfabeta.

Rivai, Veithzal. 2004. Manajemen Sumber Daya Manusia Untuk Perusahaan. PT Rajagrafindo Persada. Jakarta

Rivai, Veithzal dan Basri. 2005. Performance Appraisal: Sistem Yang Tepat Untuk Menilai Kinerja Pegawai 
Dan Meningkatkan Daya Saing Perusahaan. PT Rajagrafindo Persada. Jakarta. Robbins, Stepen, 2007, Perilaku Organisasi. Terj: Benyamin Molan. New Jersey Prentice Hall, Inc.

Sekaran, Uma. 2006. Research Methode For Business: Metodologi Penelitian Untuk bisnis . Salemba Empat. Jakarta.

Simanjuntak, Payaman J. 2005. Manajemen dan Evaluasi Kerja. Lembaga Penerbit FEUI, Jakarta.

Sugiyono. 2009. Metode Penelitian Kuantitatif, Kualitatif dan R\&D. Bandung : Alfabeta

Sukarani. 2010. Pengaruh Motivasi Dan Disiplin Kerja Terhadap Kinerja Karyawa PT. Columbindo Perdana Cabang Purworejo".

Terry R, George. 2003. Prinsipprinsip Manajemen, Bumi Aksara : Jakarta.

Thaha, Miftah. 2004. Kepemimpinan dalam Manajemen. Jakana: Raja Grafindo Persada

Tika, P. 2006. Budaya Organisasi Dan Peningkatan Kinerja Perusahaan. PT Bumi Aksara. Jakarta. 